\title{
The Requirements for the Development of Small and Medium Enterprises in Croatia and the European Union
}

\author{
Goran Kutnjak, Matija Radović \\ University of Rijeka, Rijeka, Croatia \\ Diana Blašković \\ Pharmacy "Ilona Lenac", Pazin, Croatia
}

\begin{abstract}
Small and medium enterprises are the main institutional medium of the European economy. This is also recognized by the government of the Republic of Croatia, which emphasizes their importance and values their dynamism and capability for revitalizing the Croatian economy, and supports this by ways of subsidies. But, for all the effort, the economic position of small and medium enterprises in the terms of globalization is becoming more complex and uncertain, limited by time and more demanding. This does not correspond with the thesis which states that in the environment and conditions of the modern market economy, which is dynamised by progress in science, technology, information and communication, entrepreneurship has manifested a progressive dimension with the character and needs of all economic activity, as well as a tendency to achieve set objectives and generate change. Recently, after the repeated recession, which was encumbered by the effects of the one before, the conditions of doing business and survival for small and medium enterprises have changed significantly in a negative sense. So, there is a justified cause for questioning earlier stances about small and medium enterprises and their capability to be a motor of development of the Croatian economy, as well as to reevaluate their influence in the context of GDP growth, to focus on the importance and prevalence of certain sectors of the economy, to critically evaluate economic measures which do not lead to a reduction in unemployment and to define the requirements for future development of the small and medium enterprises, which implicates the increased economic efficiency, quality and living standards.
\end{abstract}

Keywords: requirements, development, small and medium enterprises, Republic of Croatia

\section{Introduction}

Modern entrepreneurship has a dominant role in economies and societies, and those are often labeled as entrepreneurial economies, or entrepreneurial societies. Today's modern entrepreneurship, which is the most prominent in the economic sphere of society, represents a result of intense change in economics, technology, and

Goran Kutnjak, Associate Professor, Faculty of Economics, Business administration, University of Rijeka.

Matija Radović, Assistant, Faculty of Economics, Business administration. University of Rijeka

Diana Blašković, Ph.D. student, Pharmacy "Ilona Lenac".

Correspondence concerning this article should be addressed to Goran Kutnjak, Ivana Filipovića 4, 51000 Rijeka, Croatia. E-mail: goran.kutnjak@efri.hr. 
politics in the world. In the liberal phase of capitalism it has achieved a remarkable evolutionary prosperity, in the monopolistic state-capitalist phase it faced stagnation, and a near-collapse in command economies. In the most recent scientific-technological age specific for market economies, entrepreneurship has received full affirmation and expansion. The historical and developmental complexity of entrepreneurship and its futuristic outlook insist on its organization through companies. Entrepreneurship appears to be a "general need" in all segments of society, independent of the heterogeneous spheres of interest: firms, institutions (including the state), profit and non-profit organizations. Inside every activity of a "society of change" there is a tendency to achieve defined objectives, primarily by changing set constants and new affirmation by setting more efficient, more adequate relationships, i.e., to articulate social interrelationships and the system of the work process. It is beyond question that the society is the first environment with which entrepreneurs must align their interests, so it is necessary that the interests of the state and other institutions converge with those of the entrepreneurs. Therefore, to achieve entrepreneurial goals, a procedure to receive approval of the state is necessary to invest capital in a needed sector at a given time and under given conditions, and to be compatible with the laws of the state and society (Ruža, Veselica, Vranešević, Cingula, \& Dvorski, 2002). The dynamics and character of general social change manifest themselves differently not only in the quality of life, but also on the application of values of those changes in entrepreneurship.

Entrepreneurship is the accelerator of a state's economy, it is the key element to increase a society's competitiveness by generating growth and creating jobs. Its importance and complexity are apparent in many factors-economic, technological, sociological, and it includes employment, development, stability, and the level of education. Developing entrepreneurship strengthens the economy as a whole, through which material independence is obtained and hence the citizens' living standard is increased. Therefore, entrepreneurship should be incorporated in the economic and social system to secure their efficient functionality and development as well as the requirements of economic growth and social well-being.

Today, the question of emphasis on certain economic sectors (that is, the prevalence of one over the other) is given much attention to primary and secondary activities which have been considered as real and productive for a long time. Because of that, the service industry is still being thought as unproductive without proper argumentation. But there is a worldwide trend of increasing importance and efficiency of the service sector, which is confirmed by GDP growth in developed countries and developing countries during the 1970s and 1980s. The service sector today comprises more than $60 \%$ of the GDP of the world economy which by service as a means of exchange manifests market value for both the supplier and consumer. Also, almost a decade ago, the percentage of employees in the service sector was in the range of $51.9 \%$ to $75.9 \%$ in certain European countries (Vujić, 2010). It is possible to conclude that modern entrepreneurship participates in a growing service sector of national economies, therefore it demands special attention and thought, especially in the context of extending institutional support to small and medium enterprises within the bounds of those sectors.

\section{Small and Medium Enterprises in the European Union}

In the European Union, about $99 \%$ of firms are established as small and medium enterprises, which is a binding argument that this question is approached to as a priority sociological phenomenon, because it gives a key to the solution to many existential questions of modern society-economic growth and development, 
competitiveness of firms, opening and retaining jobs. Small and medium entrepreneurship (SME) is an important part of every national economy, holding $60 \%-70 \%$ of all employment in the national economies of Europe. SME represents the key factor of social and economic stability. Therefore, the concept of creating competitiveness in small and medium enterprises within the EU is an acceptable solution by which the European community is trying to counter the competitive markets of North America and the so-called Asian Tigers, with the objective of being the survival of the European industry and entrepreneurship on a global scale. However, in spite of all the developmental determinants, the fact is that in the conditions of modern business, enterprises are faced with much difficulties in finding successful solutions to attain a stable economic presence and operative security for any future period.

Other sources state that small firms are the generators of new jobs, innovation, economic dynamics, and stronger social involvment in the European Union. Those firms add up to $99.8 \%$ of all firms in the EU, in comparison with the 43,000 large firms which make up only $0.2 \%$ of the total number of firms. In 2007 , the European Union (EU-27) had over 20 million small and medium enterprises which employed about 75 million people (two thirds of the total workforce of the EU). About $30 \%$ of those firms pointed out growth as their main objective, as well as reducing administrative costs by $25 \%$ in 2012 . That could increase the European GDP by an extra 150 billion Euro which would indicate a GDP growth of about 1.5\% (Audretsch, Horst, Kwaak, \& Thurik, 2009). To make that happen, it is necessary that equal effort is exerted by the European Union and its member states. The number of small and medium enterprises is growing progressively from year to year in a far more dynamic fashion than large firms, which can be read from the following Table 1 (Audretsch et al., 2009).

Table 1

The Change in the Number of Firms in the EU From 2002 to 2007

\begin{tabular}{lrll}
\hline & \multicolumn{3}{c}{ Number of firms (million) } \\
\cline { 2 - 4 } & 2002 & 2007 & Change 2002/2007 \\
\hline Small and medium firms & 18,348 & 20,409 & +2061 \\
Large firms & 41 & 43 & +2 \\
Total & 18,389 & 20,452 & +2063 \\
\hline
\end{tabular}

Small and medium enterprises are the foundation of almost all developed economies, that is, the elementary institutional form of the European economy. The majority of employment is in such enterprises. They come into being as a result of individual business initiative, which often has a consequence of innovation. They are the basis of economic growth and development, they are more ecologically acceptable because of smaller energy use and cleaner technology. The participation of small enterprises in export is generally low, but because of highly specialized production, they have a high export potential. The European Union has set entrepreneurship, as well as innovation, as a priority in the Lisabon Declaration of 2000. From those objectives, policies to encourage formation and survival of small and medium enterprises have emerged, and one of those policies is the European Charter for Small Enterprises which was also signed by the states of the Western Balkans. In developed economies, small entrepreneurs often decide to form new companies to exploit a business opportunity, whereas in transition economies, entrepreneurship is often a way out of an unfavorable social state or unemployment. Small and medium enterprises are the main source of employment, innovation, and social integration in Europe. 
It is believed that the efforts of the EU in bringing a new economy to life will only succeed if small and medium enterprises are set as the priority of development (Škrtić, 2005b).

\section{Small and Medium Enterprises in the Republic of Croatia}

The development of small and medium entrepreneurship in the Republic of Croatia had great oscillations, depending on the time period. From 1994 to 2001, small and medium enterprises created more than $50 \%$ of total revenues in Croatia. After 2001, the relative participation in the structure of total revenues had fallen, mainly because of the increased competition and the process of globalization. As far as quantitative indicators of the economic position of Croatian, small enterprises are concerned, from 1990 (when the institutional conditions for a market economy were formally created) to 1997, a true boom in the development of small entrepreneurship was registered. In that period, the number of small firms had increased sevenfold, and medium enterprise jumped by 19\%. From 1997 to 2005 there was a relatively stable number of small and medium firms, although a trend of growth should be noted in 2002 and 2003 (Škrtić, 2005a), while recently a significant number of firms are in serious problems, facing bankruptcy and liquidation due to adverse economic conditions and recession, insolvency being the main issue.

With regard to qualitative characteristics of small and medium firms, there are those which are universal for all entrepreneurs, including the ones in (Mugler, 1993):

(1) The entrepreneur is most often the owner and manager of the firm;

(2) The entrepreneur has a network of personal contacts: buyers, suppliers, and the public;

(3) The firm produces according to the individual desires of the consumer;

(4) The contact between management and employees is close and informal;

(5) Informal organization;

(6) The firm can respond quickly to changes in the environment;

(7) The firm has a small market share;

(8) The firm has one or few products and is not diversified.

Starting with the problems, which are apparent in the EU as well, the European Union has created a model for encouraging the development of entrepreneurship which is based on three priorities: removing administrative barriers, adequate financial support, and education. Some authors have tried to connect the problems related to SME activity in the European Union with some overarching elements which cumulatively form the barriers of SME activity in the Republic of Croatia what can be seen in Table 2 (Observatory of European SMEs, 2007).

It is obvious that the Republic of Croatia has a far wider spectrum of barriers, so it is safe to say that entrepreneurs in the SME sector in Croatia have more problems, i.e., access to entrepreneurial activity is far more complex than in the European Union. Along with these problems, the development of small and medium entrepreneurship is encumbered by additional difficulties which show their resistance to all efforts of the state to resolve them. Those are (Singer, 2004):

(1) an inefficient judicial system;

(2) property records;

(3) an educational system not focused on entrepreneurship and related topics;

(4) getting loans. 
Table 2

Barriers to SME Activity in the EU and the Republic of Croatia

\begin{tabular}{|c|c|c|c|c|}
\hline SME activity barrier in the EU & \multirow{9}{*}{+} & SME activity barrier in Croatia before joining the EU & \multirow{9}{*}{$=$} & \multirow{9}{*}{$\begin{array}{l}\text { žBarriers for SME } \\
\text { activity in the Republic } \\
\text { of Croatia after joining } \\
\text { the EU }\end{array}$} \\
\hline Limited demand & & Unprofitability & & \\
\hline Administrative boundaries & & Unequal regional development & & \\
\hline Lack of qualified labor & & $\begin{array}{l}\text { Lack of coordinated policies for creating a favorable } \\
\text { business environment }\end{array}$ & & \\
\hline Problems with infrastructure & & Underdeveloped financial markets & & \\
\hline Limited financing & & Corruption & & \\
\hline The application of new technology & & & & \\
\hline $\begin{array}{l}\text { The application of new } \\
\text { organizational structures }\end{array}$ & & & & \\
\hline The lack of qualified management & & & & \\
\hline
\end{tabular}

The differences between SME and large firms are evident in the narrow-scope and broad-scope strategies with all the advantages and disadvantages of approaches in Table 3.

Table 3

Approaches to Measuring Efficiency

\begin{tabular}{|l|l|}
\hline Narrow-scope & Broad-scope \\
\hline Specialization & Generalization \\
\hline Concentration on quantity and know-how & Focus on information and systems \\
\hline Specialized production processes & A comprehensive production process \\
\hline Automatization & Mobile automatization \\
\hline Quality due to control & Quality due to process handling \\
\hline Hierarchical and beaurocratic systems & Network system \\
\hline Large round flow & Several smaller flows \\
\hline "One behind the other" & "One with the other" \\
\hline
\end{tabular}

It is beyond question that focusing on just one of the two philosophies would be unacceptable, that is, a wrong approach. Therefore, the stability of the Croatian economy must be found in a balance between the two approaches.

The importance and complexity of entrepreneurship are evident in many factors which have a direct impact on it, from economic and technological to soicological, and include employment, developments, social stability and education. The development of entrepreneurship strengthens the economy as a whole, which leads to material independence and a higher standard of living. Therefore, entrepreneurship should be incorporated in the economic and social system to increase their functionality and development and secure the requirements for a growing economy and social well-being. This conclusion is supported by the OECD (Organization for Economic Cooperation and Development) which emphasises that competitiveness is the measure of a country's ability to produce goods and services which meet international standards in a free and egalitarian market, while at the same time retaining the long-term increase in the real incomes of its population (Kutnjak, 2010).

\section{The Requirements for the Development of Small and Medium Enterprises in Croatia and the European Union}

The global market favors large firms because they are associated with large investments, market research, 
advertising, huge capital strength and so on, which small and medium enterprises cannot hope to parry. However, the SME sector provides an opportunity to apply modern solutions and practices of developed countries, on which their competitive and economic strength is based. This primarily means: the transfer of modern technologies, a larger share of investment in research and development, constant innovation, adaptation to market changes, application of the newest trends in management and organization, inclusion in worldwide trade, and encouragement of an entrepreneurial spirit which always moves the boundaries of firms, economies, and countries (Kersan-Škabić \& Banković, 2008). The fact is that entrepreneurs are faced with many obstacles. Compliance with administrative regulations and associated costs are a significant burden. In spite of the recent improvements, entrepreneurs still believe that administrative barriers are the basic obstacle in starting a business. On the other hand, education should encourage entrepreneurial activity through nurturing a right way of thinking and a sense of opportunity. Having in mind the fact that personal and organizational skills are also of vital importance to achieve success, those skills should be recognized and encouraged in early phases of education. Adequate tax measures can also contribute to the development, growth, and survival of companies. The complexity of taxation systems is an administrative burden in and of itself. The bottlenecks in the labor force create difficulties which can slow down growth-more effort is required to develop worker skills and qualifications. The growth of demand for highly qualified labor has surpassed supply. Today, many entrepreneurs are involved in lifelong learning programs, but at different levels (Zelena knjiga—Poduzetništvo u Europi, 2003). To exploit the advantages of the internal market of the EU and to face the challenge of stronger competition, Croatian entrepreneurs should be encouraged to innovate and internationalize. They should have access to relevant information, contacts, education, and top-notch assistance. The pressure of competition entices firms to continually use new knowledge and innovation.

Small and medium enterprises are key to achieving growth and creating new and better jobs which are the two most important goals of the Lisabon strategy. They represent the greatest source of employment, entrepreneurial skills, innovation as well as economic and social cohesion in the EU. By increased efficiency and innovation in firms in terms of organization, processes, products, services, and markets, the competitive strength of the economy grows. This process gives consumers an advantage by offering a wider choice of products and lower prices (Škrtić \& Mikić, 2006). For the development of small entrepreneurship there are several criteria to be met: knowledge, capital, and social influence.

\section{Conclusions}

The European Union and the Republic of Croatia have a common goal with respect to the treatment of small and medium enterprises, their importance and further development. With that in mind, the EU has set a priority objective: to be the most competitive and dynamic economy in the world, based on knowledge, capable of sustainable growth, with a tendency to increase the number of quality jobs and to strengthen social cohesion. The government of the Republic of Croatia has pointed out small and medium enterprises as an especially important developmental resource and a generator of growth in the Croatian economy as a whole in its project "Croatia in the 21st Century". Although the small and medium firms in Croatia lag behind their European counterparts significantly, the EU is still an opportunity for Croatian businesses. In cooperation with businesses from the European Union, Croatian SME's can and must use their own imagination, individuality, creativity, and business 
spirit. Small entrepreneurship does not stand a chance to prosper if it stays on the local market. A unified Europe opens a window of opportunity as well as a learning experience for Croatian businesses on a regional market with cooperation and joint ventures with small, medium, and large businesses of the EU. The European Union is more of an opportunity than it is a pitfall for Croatian SME's if, of course, the opportunity can be recognized and exploited (Škrtić, 2005c). Such a conclusion is supported by the OECD, which points out that competitiveness is the measure of a country's ability to produce goods and services which meet international standards in a free and egalitarian market, while at the same time retaining the long-term increase in the real incomes of its population. It is worth noting that forumlas for success do not have to be, and generally are not, the same for every situation. With that in mind, conforming to external conditions depends on balance, mobility, and specialization of future development as well as fulfilling objective requirements for development and their criteria. With that, small and medium enterprises ensure competitiveness, minimize the tendency to monopolize, and increase wealth and diversity of supply as producers.

\section{References}

Audretsch, D., Horst, R., Kwaak, T., \& Thurik, R. (2009). First section of the Annual Report on EU small and medium-sized enterprises. EIM Business \& Policy Research (p. 12).

Kersan-Škabić, I., \& Banković, M. (2008). Malo gospodarstvo u Hrvatskoj i ulazak u Europsku uniju, Ekonomska misao i praksa, $X V I I(1), 57-76$.

Kutnjak, G. (2010). Europska unija u funkciji poticanja i razvoja malog i srednjeg poduzetništva, Poslovna izvrsnost, God. 4, br. 2 ., Ekonomski fakultet u Zagrebu, Zagreb (p. 80).

Mugler, J. (1993). Betriebswirtshaftslehre der Klein und Mittelbetriebe (p. 17). Springer, Wien, New York.

Observatory of European SMEs. (2007). Bruxelles, Europska komisija. Retrieved from http://www.ec.europa.eu/enterprise/policies/sme/files/analysis/doc/2007/02_summary_en.pdf

Politike i aktivnosti EU_Poduzetništvo, Ministarstvo vanjskih poslova i europskih integracija. Retrieved February 27, 2012, from http://www.mvpei.hr/ei/default. asp?ru=539 \&sid= \&akcija=\&jezik=1

Ruža, F., Veselica, V., Vranešević, T., Cingula, M., \& Dvorski, S. (2002). Ekonomika poduzeća. TIVA, Varaždin (p. 13).

Singer, S. ( 2004). Razvoj sektora malih i srednjih poduzeća, westernbalkans (p. 8). Zagreb.

Škrtić, M. (2005a). Hrvatsko malo poduzetništvo i Europska Unija (p. 116). RRiF, No. 9., Zagreb.

Škrtić, M. (2005b). Hrvatsko malo poduzetništvo i Europska Unija (p. 119). RRiF, No. 9., Zagreb.

Škrtić, M. (2005c). Hrvatsko malo poduzetništvo i Europska Unija (p. 120). RRiF, No. 9., Zagreb.

Škrtić, M., \& Mikić, M. (2006). Gospodarsko značenje hrvatskoga poduzetništva—šanse i zamke. Zbornik Ekonomskog fakulteta u Zagrebu, 4, 191-203.

Vujić, V. (2010). Poduzetništvo i menadžment u uslužnim djelatnostima, Fakultet za menadžment u turizmu i ugostiteljstvu (p. 64). Rijeka.

Zelena knjiga-Poduzetništvo u Europi. (2003). Bruxelles, Europska komisija. Retrieved from http://www.hgk.biznet.hr/hgk/fileovi/493.doc 